105

Vazantes

volume $04_{-}$n. 01

\title{
Vinícius Bandera> No cinema como na literatura
}

\section{Resumo}

A intenção do poema não é didática, mas tecer uma analogia, livre (não academicista), entre o processo de construção na literatura e no cinema. O processo de construção não clássico-narrativo, porém inventivo, ou seja, o romance inventivo e o cinema inventivo, nos quais a estética se sobrepõe à linguagem. De acordo com tal analogia, a linguagem equivale a um cerceamento da liberdade e a estética ao inverso.

Palavras-chave: Estética. Experimentação Contemporânea. Cinema. Literatura.

Autor dos livros: Ordenação social no Brasil: liberalismo, cientificismo e menores abandonados e delinquentes (Ed. UFRJ). A genealogia em Foucault: do poder baseado na soberania ao poder panóptico (NEA Edições). Mulheres da vida (Ed. Multifoco) e Náufragos da fé (Laços Editorial). Pós-doutorado História (USP). Doutorado Sociologia (UFRJ). Mestrado Ciência Política UNICAMP). Professor universitário. viniciusbandera@gmail.com 


\title{
Vinícius Bandera In cinema as in literature
}

\begin{abstract}
The purpose of the poem is not didactic, but to weave an analogy, free (non-academic), between the process of construction in literature and cinema. The non-classic-narrative process, but the inventive construction process, in other words, the inventive novel and the inventive cinema, in both the aesthetics overlap with language. According to such analogy, language is equivalent to a restriction of freedom and aesthetics is the contrary.
\end{abstract}

Keywords: Contemporary Art. Literary Aesthetics. Cinematographic Aesthetics. Literary Language. Cinematographic Language. 


\title{
Vinícius Bandera En el cine como en la literatura
}

\author{
Resumen \\ La intención del poema no es didáctica, sino de tejer una analogía, libre \\ (no académica), entre el proceso de construcción en la literatura y en \\ el cine. El proceso de construcción no clásico-narrativo pero inventivo, \\ es decir, la novela inventiva y el cine inventivo, en ambos la estética se \\ superpone al lenguaje. Según tal analogía, el lenguaje equivale a una \\ restricción de la libertad y la estética a la inversa. \\ Palabras clave: Arte Contemporáneo. Estética Literaria. Estética \\ Cinematográfica. Lenguaje Literaria. Lenguaje Cinematográfico.
}


Narrativa discursiva e de correspondências.

Tudo isso sobre o material bruto.

Godard: mise-en-scène.

Do filme, a montagem é o coração.

Tempo, fluidez, percepção e assimilação.

Montagem cria associações.

Imitar o mundo (mímesis).

$\mathrm{O}$ que acontece na

No filme o que importa

não é

a realidade, mas o que dela

possa extrair a imaginação

Chaplin

Tela (enredo): ato de pensar, analisar. Criar: conceber um filme por diversas Técnicas de associações de imagens. O nascimento de uma nação de Griffith.

Intolerance criou o close. Mellies inventou a trucagem: fogos de Artifício, cortes, mudanças de ângulos, Planos fixos e movimentação de atores.

O processo do romance.

O romance do processo.

O que é o romance?

O que pode um romance?

O que cabe num romance?

O romance é uma vida real,

Porque o romancista cria

Um mundo novo, seu,

No qual a realidade não está ausente.

Sua presença é consequente, inconsequente.

É a vida a não poder explicar a que veio.

Ter as personagens como fio condutor. 
Leite, leitura

letras, literatura,

tudo o que passa,

tudo o que dura

tudo o que duramente passa tudo o que passageiramente dura tudo, tudo, tudo

não passa de caricatura

de você, minha amargura

de ver que viver não tem cura

Paulo Leminski

Soltar suas rédeas.

A carruagem que não é a de Platão.

A razão fora da ação.

A ação de criar situações

Em torno das personagens.

Capítulo por capítulo, tópico por tópico.

Íntima relação entre enredo e personagens.

O romance como uma divina comédia humana.

Inferno, purgatório, paraíso.

Misturar ou não misturar

Romance com ideologia.

Prudência em não tornar

O romance um panfleto.

Romance que não acaba com a

Leitura do leitor, detalhes, descrições,

Sentimentos, gestos, a existência acima da história,

A preceder a essência.

A desrealização do real.

O raccord tem a função básica

De dar a sensação de que não houve corte.

Dar a sensação de continuidade fluida.

Raccord de entrada e saída de campo.

Raccord de gestos, raccord de olhares.

Raccord de sons.

Continuidade da sequência e do olhar.

Montagem clássico-narrativa.

Griffith: plano curto versus plano sequência

Corte com raccord impreciso.

Dois planos fechados: é mais difícil o corte.

Corte com dois planos fechados é mais difícil o corte 
Planos imediatos, um ao outro, é mais difícil ainda.

(Aqui está implícito "o corte" depois de "ainda", por isso a concordância está no singular. Toda esta estrofe se refere ao corte na montagem - raccord também é um tipo de corte). King Vidor: The crowd.

O processo do romance: as personagens podem

Levar o escritor a desenvolvê-las.

Matéria de carpintaria literária.

Escrever um ensaio sobre literatura.

Apresente uma personagem usando

Apenas ações e gestos. Pense em detalhes para

Mostrar/apresentar como a personagem é ou

Está em seu aspecto psicológico e mesmo físico.

Quem é ele ou ela? Como é? Onde vive?

O que quer? Em que momento está?

Como vê o mundo e reage a ele?

Com quem se relaciona?

O autor orienta as personagens ou as segue?

E o diretor fílmico?

Em minha opinião, a pontuação empobrece a estética do poema.

Com pontuação o poema passa a ser gramatical, racionalis-

ta, em lugar de

pretender ser inventivo, criativo, imaginativo. O compromisso do poema não é com

razão gramatical, mas tentar se aproximar da imaginação, do não academicismo.

Gosto da Vazantes, principalmente por seu espírito inventivo. 